\title{
Gangs and governance in Russia: the paradox of law and lawlessness
}

\author{
Svetlana Stephenson \\ School of Social Sciences, London Metropolitan University, London, UK
}

[The Version of Record of this manuscript has been published and is available in Global Crime, 28 July 2019, https://www.tandfonline.com/doi/full/10.1080/17440572.2019.1645654]

\begin{abstract}
The paper addresses the nature of gang governance. It questions the notion that gangs regulate social and economic transactions and create stable orders in certain territories. It shows that, while presenting themselves as upholders of the 'law' in their territory, the gangs also create a climate of uncertainty and fear. The gangs manipulate their own unwritten rules and set up traps for residents and businessmen. These traps are designed to deprive nongang civilians of presumed rights and identities and extort their money. The paper uses Schmitt's notion of 'state of exception' and Agamben's idea of 'bare life' to explain how gangs function.
\end{abstract}

\section{Keywords}

Gangs; organised crime; criminal governance; street violence

\section{Introduction}

There is a growing agreement in gang and organised crime literature that gangs and organised crime groups across the world are not just destructive forces of crime and disorder, but that they can also participate in governance. Where state governance is weak or absent, criminal governance in certain circumstances can allow economic activities to proceed and daily lives of citizens to acquire a degree of predictability. An implicit social contract may be in place, in which criminal agents of governance deliver a range of services such as dispute resolution, debt collection, protection against crimes when committed by outsiders, as well as some welfare services to the residents, all in return for obedience and tributary payments. As many authors studying racketeering gangs and mafias have argued, these non-state actors often start as ruthless predators but ultimately become invested in providing peaceful order and predictable taxation. ${ }^{1}$ Informal regulation helps to sustain social order in a territory, or in a sector of the illicit or criminal economy, and it can acquire a degree of legitimacy. ${ }^{2}$ Micro-governance by neighbourhood gangs has also been shown to play an important role in the daily lives of citizens, shaping the space of the territories they control and creating alternative social orders. ${ }^{3}$

Some gangs and organised crime groups may aspire to establish a regime of supreme control in their areas, becoming sovereign agents. The notion of sovereignty has long been associated with ultimate authority within a territory, i.e. authority which is absolute rather than partial. ${ }^{4}$ Over time, the nation state became the only structure of sovereignty within its 
territorial borders, ${ }^{5}$ and Max Weber famously saw the monopoly over the legitimate use of physical force as the basis for the state authority. ${ }^{6}$ However, spaces where state penetration is difficult or where it can be successfully subverted, can, it has been argued, develop their own regimes of sovereignty. As Robert Latham argued, 'in late modernity both the state and a diverse range of non-state actors . . can be central to the government in an increasingly wide range of social domains', creating regimes of 'social sovereignty'. ${ }^{7}$ This sovereignty, according to Latham, is manifested in the ability to set laws, classifications and identities, specific to a particular area of social life. There has also been discussion of 'localised forms of sovereignty', ${ }^{8}$ or autonomous ruling regimes that share their sovereignty with the state. ${ }^{9}$

At the same time the world of illegal governance is also a world of explosive violence, uncertainty and fear. Unpredictable and sometimes extreme violence is used by organised crime groups and gangs against businessmen and residents, and the very horrors that their rule is supposed to eliminate, are inflicted on the subjects of their power. Research based on the study of court documents and interviews with gang members, businessmen and residents in Italy, Columbia and Russia has demonstrated a high degree of volatility of criminal rulers, with members of illegal organisations reneging on their promises, taking away the businesses of their clients or killing them, behaving towards both businessmen and residents in unreliable and treacherous ways, ${ }^{10}$ and even promoting acceptance of violence as a tool of conflict resolution. ${ }^{11}$ Wherever we talk about criminal governance we have to concede that while it can establish a semblance of social order, at the same time it creates a climate of fear and makes life in the community even more violent. The paradox of criminal governance seems to be that the rulers can see themselves as governing agents, who set the law in their territory, while simultaneously believing in their own impunity and behaving with unpredictability and ruthlessness wherever it suits their interests. At the same time businessmen or local residents may also believe that gangs or mafias have 'the law' but live in fear of explosive and extreme violence delivered by the 'legislators'.

This paradox of lawlessness as a constitutive part of criminal governance is explained by some authors as arising from the imperative for members of organised crime groups or gangs to build a reputation for violence that would allow them to minimise the actual use of violence.$^{12}$ In the absence of the stable institutions of legal and rational order that are only possible in modern states, periodic displays of violence help to sustain the power regime in which criminal organisations can be seen as a credible force. Other authors, however, refer to the intrinsic duality of criminal governance. As Federico Varese has demonstrated, in his review of studies of mafia protection, while the mafia does sometimes provide real protection, this can also turn into violent extortion; he notes that 'Mafias (and states) do both'. ${ }^{13}$ Analysing the existing accounts of protection rackets in Russia, Caroline Humphrey also argues that racketeering involves a combination of predation and provision of a service. While effectively selling their law, 'the powerful are expected to dictate their terms and be jealous and punitive too'. ${ }^{14}$ Humphrey is sceptical about seeing gangs as rational agents capable of stable governance. She argues that overpredation on the sources of income, unnecessary and extreme violence to which the users of protection are often submitted are evidence of the gangs' irrationality and a lack of imagination to perform genuine regulatory and quasi-state functions. ${ }^{15}$ I would argue, however, that wilful volatility, rather than being a sign of the gangs' 
deficiencies as enforcers and rulers, is the ultimate expression of criminal power - just as it is of state power.

The unpredictability and capacity to suspend legal and normative order on which individuals or businesses have come to rely is not limited to gangs and is profoundly implicated in the whole nature of power. As Karl Schmitt ${ }^{16}$ and, following him, Giorgio Agamben ${ }^{17}$ proposed, the state of exception is the paradigm of power. Here the law is suspended and the subjects are plunged into a situation that they experience as lawless and anomic. In place of normal law that gives certain protections to the citizens, a new order may emerge that negates the law, and where individuals suddenly face the prospect of annihilation or being placed at the margins or outside the borders of the community. They become what Agamben called 'bare life', ${ }^{18}$ defined through subjection to sovereign power and 'capacity to be killed'. ${ }^{19}$ State sovereignty rests on the state of exception, and law itself may be vague and unclear and applied inconsistently, signifying nothing other than the pure power of the sovereign to make decisions about the lives of his subjects. Arguing with contractual understanding of the nature of sovereignty, Agamben instead interprets Hobbesian ideas about sovereign power as meaning that 'the foundation of sovereign power is to be sought not in the subject's free renunciation of his natural rights but in the sovereign's preservation of his natural rights to do anything to anyone, which now appears as the right to punish'. ${ }^{20}$

This understanding of law and lawlessness as two dialectically connected parts of sovereignty, when applied to criminal sovereignty, makes it possible to see the situational, vague and unpredictable exercise of power by illegal agents of territorial governance as an intrinsic part of their rule. The illegal rulers, and members of the public, may subscribe to the ideology according to which organised gangs or mafias act to prevent lawlessness (in Russia this ideology is expressed in the widely held belief that they stand against bespredel, criminal slang for lawlessness). However, the right to impose their will regardless of the law that they claim to uphold is constitutive of criminal power - in the same way as it is a constitutive part of sovereignty of the modern state. Instead of undermining the rule, it sustains it.

In this paper I describe the world of gang governance as a world of sovereignty, which, following Agamben, ${ }^{21}$ I see as power over life, as a form of authority in which law and lawlessness are co-present. The space in which gangs operate is a space where application of alternative gang law and conduct codes are vague, and a person can be placed in a terrifying space of simultaneous presence and absence of law. In this space of exception, the rules of 'orderly' behavior are often suspended or inverted and replaced with norms that are unknown and have to be guessed at, or where they suddenly do not apply, with the ultimate possibility of violence or even death. Vagueness and the terrifying prospect presented to the residents and businessmen of turning into bare life, are political strategies and the expression of sovereign rule. I suggest that political strategies of the gangs can be analysed as strategies of entrapment, constructions of traps, which I see as spaces/positions into which the power holders, using deceit and obfuscation, manoeuvre individuals in order to strip them of their rights, identities and capacity for purposeful action. A trap is a space of exception, where the subjects of power find themselves at the mercy of the powerful. In this paper I analyse the traps that are set by the gangs through verbal communication with members of the population (I call them 'civilians'), and the traps inherent in the relationship of criminal protection. 
The processes of entrapment can be studied both from the perspective of the victims, and from the perspective of the gang members. In this paper I look at both. I analyse advice published on Russian Internet sites on how to behave in the event of encountering a violent street gang. These Internet resources, such as the sites dedicated to martial arts and fighting skills (iskusstvoboya.ru), weapons (guns.ru), prisons and prison culture (tyurem.net), or similarly themed specialised forums on pikabu.ru (the Russian analogue of reddit), contain posts and conversation threads by members of the public. The contributors are adults and young people, predominantly male, from across Russia who offer advice based on their own experiences of past encounters with violent street gang members (gopniki). I would argue that, in aggregate, they are representative of how social actors attempt to make sense of the street social order. This can be seen as an example of what Garfinkel termed 'reflexivity', where actors, through verbal display, attempt to identify patterns and structures in everyday reality, and use them for practical purposes. ${ }^{22}$

I also use the interviews with members of entrepreneurial gangs and local residents which I and members of my research team conducted in the Russian city of Kazan in 20052011. Kazan has been known as one of the major locations of gang activity in Russia since the 1970s, and although their presence and power have reduced in the 2000s, the gangs have remained entrenched in peripheral areas of the city, with their members conducting protection operations and victimising non-gang youth. ${ }^{23}$ The project involved semi-structured interviews with active members of organised entrepreneurial gangs, aged from 17-35 from different areas of Kazan, as well as in-depth interviews with local residents, victims of gang violence and businessmen. Gang research presents many potential problems in terms of access and developing trust. ${ }^{24}$ In this study the initial contacts were made by members of the Kazan research team (who lived in areas with high gang presence) via friends and neighbours of gang members. Access to other participants was obtained via students from the university where two members of the research team, Alexander Salagaev and Rustem Safin, worked, and through further snowballing. While some of the interviewees were personally known to the research team, they were all guaranteed anonymity and were assured that neither they nor their gangs would be identified in the transcripts and research outputs. The data (together with secondary sources on Russian gangs) are used to validate the accounts of street victimisation on Internet forums and provide further evidence on the nature of social relations inherent in criminal protection.

We need to treat the qualitative data reported in internet forum accounts and interviews with some caution. The data containing reconstructions of encounters between civilians and gang members may, in some cases, include exaggeration or concealment; street encounters are messy and unpredictable; and there may be a tendency to filter out more mundane interaction in favour of more extreme events. Some civilians, those more savvy in the rules of the street or those with connections to powerful figures in the area, may be able to avoid the traps set by gangs and are perhaps less likely to contribute to these forums. ${ }^{25}$ However, as my main purpose in using this evidence is to identify the unwritten rules that govern communication between the gangs and civilians and to describe the overlapping understanding of the extant normative order - to which people orient themselves, and which they presume to be factual - it is the perceptions of this order expressed by participants that are of most relevance to my argument. 
There is also a question of how far this analysis is generalisable to other national contexts, as the social, cultural and economic realities and legislative frameworks can vary widely. ${ }^{26}$ This question applies to most gang and organised crime research, which is often conducted in the form of localised studies, but is nevertheless used to inform wider debates about criminal governance. ${ }^{27}$ Identifying the unwritten rules of the social order that emerge from the accounts of societal members helps us to understand the complexities of criminal power, and the malignant operation of its law, that are often dismissed in academic accounts that focus predominantly on the useful function and utility of criminal protection.

\section{The Russian gang world}

There are many definitional issues concerning the gang ${ }^{28}$ as the term is commonly applied to a wide diversity of groups, from street organisations that engage in episodic and noninstrumental violence to entrepreneurial gangs that share many definitional features with organised crime. ${ }^{29}$ Russian gangs are also typologically diverse. These can be neighbourhood peer groups that come together to socialise on the streets without any substantial involvement in crime and violence. There are also violent male peer groups involved in territorial control in their neighbourhood, and entrepreneurial gangs, offering criminal protection. Both of the latter establish localised sovereignty in the space of the neighbourhood or wider urban territory, in which the gangs have rights over 'their' land, and in which they execute command based on their own law (poniatiia, literally 'understandings'), enforced through direct violence or its potentiality.

Violent male peer groups unite local young men aged from 12-14 to 18-20 years in many neighbourhoods across Russia, particularly in low income areas, where there can also be substantial populations of ex-convicts. Studies of these groups in the peripheral areas of Moscow and $\operatorname{Kazan}^{30}$ and other cities across the Russian Federation ${ }^{31}$ show that these young people see themselves as the key agents of the street social order. They police the borders of their community, attack their peers and groups defined as the enemies (members of outside youth groups, ethnic minorities or homosexuals), participate in arranged fights with the members of 'enemy' gangs. They are also involved in street intimidation, extortion and assault, predominantly directed at young men who do not belong to their groups. At the same time members of these gangs see themselves as belonging to rule-governed societies, and they have a code of behaviour that is perceived as an alternative code of law. This code is heavily influenced by the Soviet criminal culture and the code of the thieves-in-law (vory-v-zakone), a criminal community that originated in the Soviet Gulag whose code became widely disseminated thanks to ex-convicts settling back in the community, urban folklore and increasingly the mass media. ${ }^{32}$ The code was also adopted and modified by the new generation of post-Soviet organised criminals, the so-called bandits. ${ }^{33}$

Poniatiia prescribe particular gender performances in line with traditional constructions of hegemonic masculinity. ${ }^{34}$ Young men who embrace the code construct a persona of a 'lad', a young man who can demonstrate toughness, fearlessness, resolve, an ability to react quickly to provocation and other manifestations of 'manliness'. The code of poniatiia has prescriptions relating to the principles of fraternity, equality and fairness within the gang, as well as prohibitions on attacks against women, children and old people. Any violence towards them, 
as well as unmotivated and extreme violence towards any non-gang civilians, is seen as bespredel. Nevertheless, as I will explain later, these prohibitions are violated by the gang on a daily basis.

Poniatiia are built around a radical distinction between the lads (patsany), the members of the gangs who possess the supreme power on the streets and are owed respect and obedience, and the civilians (lokhi), the despised and passive subjects of their rule. Behaviours that are interpreted as disrespect and disobedience towards the lads need to be punished.

In some areas of Russia we also find entrepreneurial neighbourhood gangs. The members of these gangs also call themselves the lads (albeit with the added adjectives of 'real' or 'concrete' lads). Some of them are associated with serious organised crime networks of adult criminals, with thieves-in-law, and with more entrepreneurial bandits. ${ }^{35}$ Others are independent.

The gangs typically have cohort structures based on age, with active membership aged from 18-30. Younger people provide protection to their peers, demanding tribute on a regular basis, protect illicit gaming establishments, control street prostitution networks and run street drugs operations. They also re-sell stolen mobile phones, set up illicit parking lots, and some of the members are involved in street assault and burglary. The leaders of the gangs, avtoritety, together with their close associates, organise large-scale protection operations and participate in other serious organised crime activities, such as setting up various illegal schemes of tax evasion and money laundering, and run large-scale illegal drugs business. Some combine these activities with legal business. These entrepreneurial gangs subscribe to a similar code of conduct to that of the street, but their system of classifications also includes a category of komersy (businessmen), seen, together with lokhi, as being on the opposite side of the hierarchy of human worth to the lads, and owing them tribute for the right to work in 'their' territory. ${ }^{36}$

Since the 2000s, the influence and territorial presence of gangs across Russia have receded as a result of economic and social stabilisation and strengthening of the state. ${ }^{37}$ But although the power of gangs is nothing like it was in the 1990s, there is evidence of a current revival, particularly in poor, economically depressed areas of Russia. Lacking opportunities in the legal economy, young people form their own criminal groups and join the structures of entrepreneurial bandit gangs. ${ }^{38}$ No longer able to act with impunity, their leaders enter shifting competitive and collaborative relations with agents of the state. While those unwilling to subject to the power of the state are prosecuted and incarcerated, others become involved in informal trade-offs, co-operating in elections, devising collaborative illegal schemes and using each other's violent resource. ${ }^{39}$ The state can allow the gangs to develop regimes of localised sovereignty - as long as their leaders stay within set parameters. ${ }^{40}$ Just like other non-state agents of violence, such as vigilante groups, the gangs can impose their law, and punish transgressors, while being tolerated or even enabled by the state. ${ }^{41}$

In what follows, I describe the political strategies of street and entrepreneurial gangs that aim to establish them as agents of localised sovereignty in the territory.

\section{Political strategies of violent street gangs: the trap of conversation}

The gangs do not follow the accepted social conventions. They speak their own language and have their own rules, and they may attack a passer-by without warning, or subject him to 
interrogation according to their own judicial procedure that is unclear and incomprehensible. Within the online discussion and advice on 'dealing with' gopniki, we see how members of the public attempt to outline the rules of interaction in this world where the norms of 'civilised' behavior are suddenly and terrifyingly suspended, and defenceless, vulnerable human beings encounter what may seem as a hostile occupying force. Here, new rules that always have to be guessed at and imputed, manifest themselves. Failure to supply correct answers during the gopniki's interrogation may result in violent 'punishment', robbery and physical assault. While victims of the gangs do have the option of appealing to the police, many do not, whether because of a social stigma for a young man of appearing 'weak', or because of widespread belief that such appeals will only be met with inaction by disinterested or corrupt officers. ${ }^{42}$

Descriptions of various encounters show that the representatives of the aforementioned force - the lads or gopniki - improvise, and express themselves through evasions and hints, but their behaviour has its own underlying logic. What emerges is not simple situational manipulation that puts the victims on the defensive at a particular moment in time, what Collins calls a 'claim to dominate the interactional space', ${ }^{43}$ but thoroughly political behaviour. It is aimed, I would argue, at establishing themselves as agents of sovereignty in their local turf who have power over life and have the right to dictate the rules. They are the source of law with the power to decide who is guilty and who is not according to their own code, while a lack of understanding of their laws (in similarity with other legal systems) does not eliminate guilt. In fact, not knowing the rules already constitutes guilt.

According to the authors of the advice, there are two types of encounter with members of the street gangs. One is known as 'assault through bespredel', in other words, assault through lawless violence. This is where the gopniki blatantly tell you to give them your money or lash out at you without any preceding conversation. The power here is exercised as pure force, while the use of the slang word 'bespredel' signifies that the agents of street 'authority' are suspending their own laws. The only option for a more or less dignified exit for a civilian is to hit one of them first and then run away as fast as one can (but this can result in a delayed and potentially more catastrophic consequences if and when a person returns to the area). Alternatively, one should forget about one's dignity and just run immediately.

The other type of encounter is characterised as 'assault through conversation'. This is where a vague chance exists to avoid violence and maintain dignity by conducting oneself in a way that the potential assailants would see as legitimate according to their own code. This may work for those young people who have grown up on the street and who possess the necessary subcultural knowledge of how to behave competently within this space. ${ }^{44}$ For the rest, the chances of 'getting off through conversation' are, by common agreement, small, but they nevertheless exist, and this is what most advice tries to help with.

Descriptions of 'assault through conversation', show what Jack Katz calls 'a typical opening stratagem in street robberies - the use of civility to move into position of moral dominance'. ${ }^{45}$ Many posts describe the opening gambit by the assailants as overly polite. A member of a street group may greet the potential victim by offering a handshake. This is, however, an invitation into a trap. A handshake is likely to be followed up by an enquiry, not untypical in street worlds elsewhere, about where the victim is from, followed by a seemingly profound philosophical question: 'Who are you in this life?' This leads further into a trap. Instead of meditating on this question and coming up with insights about his place in society 
or the universe, the person needs to respond with a highly specific answer. He must describe his social status in terms that correspond to the system of classifications upheld by the interrogators and be ready to justify his answer, again using their own terms. This judicial process presumes the understanding of the laws that can only be acquired through previous experience on the streets, and even that understanding can be challenged. Failing to reply correctly, and then explain his response, he becomes immediately guilty. The main purpose of the interrogation is to establish whether one is a lad, a 'proper' man and a citizen of the street world, or a helpless civilian, a person with no rights and consequently fair game for physical assault or extortion. Ultimately, the conversation is designed to place one irrefutably in the position of a lokh, a position that corresponds to Agamben's bare life. As a result of this conversation, the interrogators may or may not decide to apply violence, but irrespective of that, the potentiality of violence always remains. In fact, this potentiality, rather than violence itself, represents their power and this is why 'assault through conversation' takes place at all.

Although the online experts present themselves as competent interpreters of street legislation and process, they warn their readers that it is not possible to give advice to people who do not already implicitly understand the rules:

It is impossible to describe every situation. Unless you have a sense of what to do ... And if you can't do it, and you don't know 'who you are in this world', then it's best simply to run away, as you will not be able to 'get off' through proper conversation, and even if you hit one of them, next time they will go after you with twice as big a crowd ('uralbrat" ${ }^{46}$ ).

Advice conveys the sense that the law is in force but it is inscrutable and any attempts by the victim to understand the clearly present regime of power, to try to guess its logic and rules, may be undermined and subverted. Like K., the hero of Kafka's The Trial (1998), a person finds himself a victim of an inherently incomprehensible judicial order that pronounces him perpetrator of a crime whose nature is unclear to him and under the laws that he does not know. Again, a lack of knowledge of the law does not alleviate the guilt and can be construed as a transgression in its own right.

That is why 'lay experts' on street law constantly repeat the advice that a person is better off not getting into a conversation and walking or running away from the trap (although this may itself be construed as a lack of respect and entail punishment).

If the gopniki shout at you: 'Hey you, come here', then you are already on the path towards a conflict. Now you should not get panicky or talk back, but you should not go towards them. Naturally, if you have already made the gopnik interested, he will come to you himself, and will, as per tradition, stretch out his hand, and this is the most important moment. By shaking his hand, you are accepting an obligation to be polite with this person and answer his questions, which is exactly what he is relying on. ${ }^{47}$

The implicit understanding of the logic of entrapment is frequently shown by the authors of the advice, as in the following quote from a forum participant with the nickname 'vovanoid': 'Do 
not give any direct answers to the questions that follow their script, otherwise they will put you through a real interrogation and will take issue with your answers' ${ }^{48}$

The best strategy, then, is not to respond directly to any questions asked by a gopnik (just as those accused of crime by police are often advised to keep silent). One can rarely win in this interaction, and risks being drawn more deeply into the trap. Furthermore, according to one forum participant, once a person responds, he finds that 'as soon as you want to stop an unpleasant conversation, the aggressor will have a pretext to accuse you of disrespecting him and move to a physical attack'. ${ }^{49}$ 'uralbrat' explains:

If they come up to you with a conversation, like 'Hey, guy, do you live here? . . . In such situations if you strike first you will be wrong according to poniatiia . . . And if they later find you and fuck you up they will be right according to poniatiia ... So my advice is to behave with confidence and not to speak of what you don't know. For example, they ask you 'Who are you in this life?' A person who knows, he will know what to say (there is no standard answer, you must name yourself by what you really are). But a person who does not know will stumble here ... So they will ask 'Are you a lad at all?' Of course, you will say, yes, who would say no??? And now the most interesting part: 'Justify your answer, show that you are a lad'. Now you are in a stupor, how can I justify it? I understand of course that a person who grew up on the streets can answer 'properly', and if not, his mates will help him afterwards ... But a person who lacks the street experience, who used to take music lessons, who was an exemplary boy in school, how can he respond to something he does not know? ... I think it's impossible. One should answer 'I am a guy' or 'I am a male'. Now if they ask (and I insist, ask, and do not simply get into your pocket for money etc.), 'Have you got any money?' If you say you don't have any, and they discover money in your pocket . . . they say you owe them, explain why you are a pizdobol [liar], and liars, as it is well known, always owe money ... ${ }^{50}$

In the same conversation, another participant with the nickname 'Kodak', says:

In order to be able to get out through conversation you need to know poniatiia, and you can only get information about them from ex-convicts and, paradoxically, via mass media. However, if they want to rob you or beat you up, they may neglect your knowledge of poniatiia and the ability to speak fenia [criminal slang], and a person who came from prison would suss it straight away if you want to fake it.

According to Kazan gang researcher Alexander Shashkin, interrogation ultimately aims to produce a sense of worthlessness, 'a life unworthy of being lived' (as Agamben would put it). ${ }^{51}$ Victims are made to experience a sense of guilt of having violated the extant law. In his analysis of interview data with gang members and their victims, Shashkin shows that 'gang members manage to instil a sense of guilt even when the situation does not presume somebody being right or wrong; the victim is being persuaded that he is "not right"" 52

If a person complies with the gang's demands for money, they become liable to continuous extortion. A victim is labelled a terpila (passive sufferer) or a sladkii (sweet one), 
and the expectation is that he will have to pay until the gang decides it is no longer worth its while to collect the money.

In exchange for the money, the gang claims to provide a krysha (a roof - i.e. protection), promising to defend the victim from assaults from other gangs or street hooligans. It remains, however, entirely at the gang's discretion whether to provide this protection or not. Shashkin quotes a gang member who says that if a victim "ffeeds the lads", it is possible to go and negotiate on his behalf'. Another gang member, however, described the gang's treatment of the victims of extortion in a different way:

They are like dairy cows. The lads simply milk them for money, live at their expense . .. I just tell him, like, 'listen, pal, if you have any problems, just come to me, I'll help you'. That's all. If he does come, I'll just brush him off, like 'I'm busy, pal'. 'What's up,' I'd say, 'what happened?' He'd say this and that. I'd say, 'Look, pal, you are in the wrong here, and you have to sort it out. I have my own problems now, my own business to take care of. I'll not help out some chort [a person who does not live according to poniatiia]'. 53

The gangs also present themselves as agents of morality and law, and construct guilt through practices where the lads pretend to be concerned with violations of social order within the community, as described by Dmitry Gromov in his study of other areas of Russia. ${ }^{54}$ By punishing 'transgressors', they act as if out of concern for common good. Thus, 'assault through conversation' may involve an accusation that a young man has upset or assaulted an old person, a woman or a child living in the area. In most cases these offenses are totally fictitious. Sometimes a provocation, a deliberate entrapment, is involved (something that, in different forms, also happens within the state's law and order practices). For example, in a typical scenario of provoking the victim found in urban areas across Russia, the lads ask a young boy to come to a group of young men and ask them for a cigarette. When they refuse, the boy starts whining that he was badly treated, after which the gang arrives with a ready justification to attack the 'transgressors' who have just hurt a 'little one'.

In a different scenario, the 'offenders' are accused of being noisy and disorderly. For example, a group of street lads would come to a group of non-gang young men who are told that they are being too loud: 'Why are you shouting? Children and women are sleeping. Everyone's tired'. This becomes a pretext for assault. Alternatively, a person may be judged to be dressed improperly. A member of a youth subcultural group, a goth or a punk, for example, can be accused of wearing the wrong clothes: 'Why are you dressed like this? It's off-putting for people just to look at you!'

In some urban areas the local lads establish a 'curfew'. Nobody is supposed to be hanging out on the streets after a certain time. There is no problem if a person walks home quietly on his own, but if a young man is out with a girl he will be told: 'You should obey the order, get out of here', and similarly, a group of people coming into the territory can be told that they were violating the curfew. ${ }^{55}$ Through this, and the other devices described above, the lads constitute themselves as agents of social order, while at the same time, of course, violating it daily themselves. 
The trap here is constituted through the use of conventional morality to accuse the civilians of transgression. But the transgression itself is fictitious and construed by the lads with the sole purpose of establishing themselves as the agents of local power.

\section{Political strategies of entrepreneurial gangs: the trap of protection}

As my Kazan research illustrated, similarly to members of violent street groups, members of entrepreneurial gangs also acted as order making agents in the territory. Their strategies of territorial control were much more expansive, and involved, in addition to episodic street violence against local non-gang young people (committed, as a rule, by members of the younger cohorts), informal policing of the territory. They harassed drug addicts or dealers who were not part of their gangs, explaining in interviews that they were polluting the territory. They helped the residents reclaim their money and possessions from outside criminals who had committed theft or burglary in the area. During the crisis years of the 1990s, the gangs also provided the residents with food and money and even installed secure doors in the entrances to blocks of flats. In the 2000s when my research took place, this was no longer the case, but the gangs gave money to churches and mosques, funded sports facilities for young people and were involved in a range of charitable activities in the city.

The most profound expression of their role as the agents of power in the territory were their protection operations. The younger members offered protection to their nongang peers, promising to defend them from other gangs. This protection was, according to the lads' own accounts, by and large fictitious and was, in reality, thinly masked extortion. They also set up, with the help of their leaders and corrupt transport policemen, semi-legal street parking lots, forcing the car owners to pay them for an equally fictitious service. They offered the car owners secure parking, but in fact provided no recompense if a car was stolen or damaged.

The older lads and their leaders offered protection to businessmen, market traders, owners of cafes and restaurants, taxi drivers and managers of transport companies. For a share of the individuals' or the companies' profits, they provided services in resolving conflicts, collecting business intelligence, lending money or helping to find access to (corrupt) members of the police and other state authority. But rather than providers of services, gang members perceived themselves as sovereign agents who were receiving tribute from local businessmen - unless these businessmen's status allowed them the protection of the state. As one gang member, Anvar, explained,

We have our own territory, where you can't do business without the senior members' permission - no setting up stalls or parking lots or the like. Naturally, the construction of big shops like supermarkets happens regardless of the street [gang], but all the smalltime traders live under us. Anyone who wants to can walk around our territory, we don't charge tolls, but if someone wants to make dough, they've got to share because it's our territory.

Protection was unreliable, and profoundly influenced by the lads' belief that the komersy, apart from owing them money, were also inferior human beings. A komers, as Agamben would say, 
was always 'a being in-debt' ${ }^{56}$ and the gang could deprive him of any rights, ban him from the territory or kill him.

From interviews with businessmen and gang members, it was clear that the relationship of protection, for all the benefits it could potentially give, functioned as a trap. People who came under protection and started paying the gang could not stop on their own accord, and only if the protectors decided that they did not want one's business anymore could the businessmen stop paying the gang. At the same time the gang members could refuse to come to a businessman's defence by saying that they were too 'busy' (this could happen even in situations where businessmen under their protection were assaulted by criminals or members of a rival gang), or simply by not answering their mobile phones in response to calls and texts from their 'clients' ${ }^{57}$ However, any reneging on obligations by the civilians was seen by the gangs as an offence and meant an immediate and severe punishment.

Rather than contractual obligations, the constitutive foundations of the gangs' power lay in application of pure force that says, 'X needs to pay us because he lives in our territory', or ' $\mathrm{X}$ needs to pay us if he wants to work on our territory', or ' $\mathrm{X}$ needs to pay us because he violated our rules'. The civilians could always be punished for violation of the gang's poniatiia. But while the language of punishment was used both by the residents and businessmen, and the gang members, it was clear to everyone that a civilian's crime could be constructed at will, and there was always a way in which he could be defined as culpable. Looking at a gang member in a wrong way (or not looking at him at all), being slow with providing payment, even expecting the gang to offer the promised protection could all be construed as violations of the law in which the sovereign decides what is lawful and what is not. The pretexts were manifold. As Nemets, one of Kazan gang members, said: 'If you dig deep enough into anyone, you'll find some kind of flaw. And when you've found it, you can beat them up for it.'

The application of gang law was always vague and indeterminate, and as Bogdan, another gang member, said, 'To say definitively who you can or cannot beat up is impossible. Everything depends on the situation. I've used violence against those older than me, and those younger, but there was always something to punish them for.' Kirill expressed less aggressive but still very flexible views on the limits on violence: 'I prefer to resolve issues peacefully, without bloodshed, even though we can come and grind everybody into dust at any time. You have to know how to find the right solution, make mutual concessions. But even more I prefer to put people into situations where they are wrong according to poniatiia'.

At the same time, residents reported deep disorientation and terror in their encounters with gang members. The sense of being in the presence of supreme force that operates on the basis of its own inscrutable law was well expressed by one of the authors of advice or how to behave if confronted by 'real lads':

Our fear comes from not knowing the rules according to which 'that' world operates. But we inherently respect them. Because these are the rules of the strong, the poniatiia. We respect the world of the strong, the world of thieves and bandits. But there is no direct access to that world, and the full code of poniatiia is not available to us mere mortals. We accept them unquestioningly, but we do not know their principles and norms. ${ }^{58}$ 
The realisation that in the presence of sovereign power, one is reduced to being bare life was expressed well by Rustem, a local Kazan resident, who said, 'When talking to people, the gang members try to show that they are "from the street", that they have support, that they are the kings, and that you are just a lokh, and your life is theirs to do with as they will.' Another Kazan resident, Fanil, explained: 'What's crucial is that they always think of themselves as being right and will always make you wrong. If they want, gang members can always find a pretext to punish you.' They describe a situation of the sovereign exception 'in which everything that the sovereign deemed de facto necessary could happen'. ${ }^{59}$

\section{The trap as a site of power}

As we have seen, the political strategies of the gang can be often seen as strategies of entrapment. Entrapment is clearly present in both 'assault through conversation' and 'protection' scenarios. Of course, it is the nature of traps that they remain unknown to their victims, who unintentionally step into them. 'Laying a trap' is a pre-planned and carefully choreographed operation. Here a space is created where a victim suddenly finds himself at the mercy of those who set the trap and who now control the situation, possessing the victim's time, setting the limits to his mobility and effectively manipulating his emotional state. The victims do not know what it is in store for them and may believe that other rules apply to the situation. They end up confused and disorientated. They are in a space of exception, stripped of the rights they may have assumed they had, but which they decisively lack now.

A trap constitutes a site of maximum power, depriving victims not just of capacity, but often of any inclination to resist. Unlike pure force, which is purposive, direct and immediate, a trap creates a space where power can be exercised at leisure. In Crowds and Power, Canetti explained that, unlike pure force, power can also be ceremonious and slow. He used the example of a cat and a mouse to illustrate his point. Playing with the mouse, the cat does not use immediate force.

It lets it go, allows it to run about a little and even turns its back; and, during this time, the mouse is no longer subjected to force. But it is still within the power of the cat and can be caught again ... The space which the cat dominates, the moment of hope it allows the mouse, while continuing however to watch it closely all the time and never relaxing its interest and intention to destroy it - all this together, space, hope, watchfulness and destructive intent, can be called the actual body of power, or more simply, power itself. ${ }^{60}$

Traps, obfuscations, indeterminacy and vagueness, sudden changes of rules, emergence of breaks in the presumed order and radical changes in the rights and identities of the individuals that find themselves entrapped - all of these are the instruments of power, and we can, I believe, analyse them productively both in relation to criminal governance and to the modern state.

\section{Conclusion}

Gang researchers sometimes apply the metaphor of a nation to a gang. ${ }^{61}$ Gangs, like nations, establish their own borders and mark their territory, design their own insignia and symbols, 
develop mythologies and historical traditions, declare wars and set up war councils, invent initiation and expulsion rituals that are similar to the rituals relating to citizenship etc. While it is possible to interpret these practices as a continuation of childhood games, ${ }^{62}$ I would argue that they need to be taken much more seriously, as indications of the actual presence of localised sovereignty. Gangs develop their territorial monopolies of force and may also aspire to a degree of legitimacy, of being recognised as the source of law and moral regulation in the local space.

Yet the paradox of their power (and, following Schmitt and Agamben, we can say of any power) is that it also contains, and legitimises, lawlessness. The gangs create a state of exception using their law to justify deprivation of the non-gang civilians of rights and dignity. We are looking here at expression of power not as a contract but as violence. It aims to produce what Hannah Arendt called 'unquestioning obedience' rather than consent. ${ }^{63}$

The law contains its own negation as the civilians are given identities that allow lawlessness towards them. While poniatiia can contain prescriptions that limit bespredel, they ultimately express the power of the dominant group, the power that is founded on the original distinction between the sovereign agents, the lads and the powerless lokhi and komersy.

The lads' political strategies are often associated with entrapment, creation of spaces of exception in which the victim is stripped of his previous identity and may also be constructed as a person who has shown disobedience and disrespect to the masters and needs to be punished for it. This takes place in violent encounters on the streets, as well as in institutionalised relations of protection, which the civilians cannot leave and where the rights they were promised can be withdrawn. For the victims, entrapment leads to what Agamben, after Berger and Luckman, called 'anomic terror', ${ }^{64}$ a sense of disorientation and anxiety that accompanies the breakdown of expected social order.

The paradox that gang governance contains - the co-presence of law and lawlessness, order and disorder - is the paradigmatic expression of power. The gang in its brutality exposes the very features of power that may be hidden in the operation of other power regimes. The suspension of law and designation of the person or persons who are deprived of their rights as weird, unreasonable, disloyal or disrespectful, as transgressors of social/corporate/state norms and laws who brought their punishment upon themselves, occurs in many spaces where power operates. It is here that we find traps set to extract existing identities and capacity to act from individuals and reduce them to bare life. 


\section{Notes}

1. See, for example, Olson, "Dictatorship, Democracy, and Development"; Gambetta, The Sicilian Mafia; and Volkov, Violent Entrepreneurs.

2. von Lampe, Organized Crime, 76.

3. Stephenson, "The Kazan Leviathan"; Rodgers, "Living in the Shadow of Death"; Venkatesh, American Project; and Densley, How Gangs Work.

4. James, "The Practice of Sovereign Statehood".

5. Giddens, The Nation-state and Violence.

6. Weber, "Politics as Vocation," 78.

7. Latham, "Social Sovereignty," 2.

8. Humphrey, "Sovereignty," 420.

9. Stephenson, "The Kazan Leviathan".

10. Varese, The Russian Mafia; and Leibler, "Illegal Enterprises".

11. Becucci, "Criminal Infiltration".

12. Gambetta, The Sicilian Mafia.

13. Varese, "Protection and Extortion".

14. Humphrey, The Unmaking of Soviet Life, 114.

15. Ibid.

16. Schmitt, The Concept of the Political.

17. Agamben, Homo Sacer; and Agamben, State of Exception.

18. Agamben, Homo Sacer.

19. Ibid., 8 .

20. Ibid., 106.

21. Ibid.

22. Garfinkel, Studies in Ethnomethodology, 7-11.

23. Stephenson, Gangs of Russia; and Kirillov, on the current situation see "V Kazan vernulis" gruppirovki".

24. Rodgers, "Joining the Gang".

25. On street socialisation and the use of subcultural capital and local connections as a way to avoid victimisation see Stephenson, Gangs of Russia, chapter 8; and Shashkin, "Ulitsa: svoi i chuzhie".

26. See Hobbs and Antonopoulos, "How to Research Organized Crime," for a discussion of reliability and generalisability in qualitative organized crime research.

27. See, for example, Varese, "Protection and Extortion".

28. See, for example, Esbensen et al., "Similarities and Differences in Risk Factors"; and Hallsworth and Young, "Gang Talk and Gang Talkers".

29. Paoli, "The Paradoxes of Organized Crime".

30. Stephenson, Gangs of Russia. 
31. Gromov, "Podrostkovo-molodeozhnye ulichnye gruppirovki"; Karbainov, "Ei, khunkhuz, kuda idiosh?"; and Golovin and Lurie "Ideologicheskie i territorialnye soobshchestva".

32. Raleigh, Russia's Sputnik Generation; Kozlov, "Kozel na Sakse"; and Stephenson and Zakharova, "Criminal Networks".

33. Volkov, Violent Entrepreneurs.

34. Messerschmidt, Masculinities and Crime; and Connell, Masculinities.

35. On the history of these groups see Volkov, Violent Entrepreneurs.

36. For a detailed description of the code of poniatiia, see Stephenson, Gangs of Russia, chapter 7.

37. Volkov, Violent Entrepreneurs; and Taylor, State Building in Russia.

38. Belyi, "Na ulitsy Rossii vernulis' molodyozhnye gruppirovki”.

39. Favarel-Garrigues, "Mafia Violence and Political Violence"; Stephenson, "It Takes Two

To Tango"; Galeotti, Vory; and Sukharenko, "Organized Crime in Russia".

40. An example of a regime of localised sovereignty that was facilitated by the state was the village of Kushchevskaya in Southern Russia. With leaders of a local gang being personally integrated in the local power networks, they were able for over 20 years to act with impunity, expropriating land from farmers, racketeering business people, sending their enforcers to maim and kill their adversaries and sexually exploiting local women. At the same time they were involved in corrupt land appropriation and business schemes with members of the local police force and representatives of the top brass of the Prokuratura (State Prosecution Service). See Kostiuchenko, Nam Zdes' Zhit',

41. Favarel-Garrigues, "Justiciers Amateurs et Croisades Morales"; Zabyelina, "Russia's Night Wolves Motorcycle Club".

42. On the public distrust of the police and the corrupt connections between police and the gangs see Stephenson, Gangs of Russia, 156; and Salagaev, Shashkin, and Konnov, "One Hand Washes Another".

43. Collins, Violence, 350.

44. There are significant similarities here with the rituals if initiation in Polish prisons, described by Kaminski, where the newcomer must demonstrate an understanding of linguistic and behavioural norms of subculture. Kaminski shows that an informed newcomer can simulate toughness and smartness. See Kaminski, The Games Prisoners Play.

45. Katz, Seductions of Crime, 322.

46. guns.ru.

47. iskusstvo boya.

48. Ibid.

49. pikabu.ru.

50. See above 46.

51. Agamben, Homo Sacer, 138.

52. Shashkin, "Ulitsa: svoi i chuzhie," 180. 
53. Ibid., 172.

54. Cited in Zdorovova, "A cho borzyi takoi?".

55. Ibid.

56. Agamben, Homo Sacer, 26.

57. On the unreliability of gang protection in other Russian cities see Konstantinov, Banditskii Peterburg and Varese, The Russian Mafia.

58. Lozovskii, "Kto takie gopniki”.

59. See above 51.

60. Canetti, Crowds and Power, 327.

61. Thrasher, The Gang, 93; and Katz, Seductions of Crime, 117.

62. Katz, Seductions of Crime.

63. Arendt, “On Violence," 140.

64. Agamben, State of Exception, 66.

\section{Disclosure statement}

No potential conflict of interest was reported by the author.

\section{Funding}

This research was partly funded by Harry Frank Guggenheim Foundation.

\section{Notes on contributor}

Svetlana Stephenson is a Reader in Sociology in the School of Social Sciences at London Metropolitan University. Her research focuses on social transformation and informal social organisation in Russia. She studied gangs, homelessness, street children, human rights and social justice in a comparative context. Among her books are Gangs of Russia. From the Streets to the Corridors of Power, Cornell University Press, 2015, Crossing the Line. Vagrancy, Homelessness and Social Displacement in Russia, Ashgate, 2006 and Youth and Social Change in Eastern Europe and the Former Soviet Union, Routledge, 2012 (co-edited with Charles Walker). 


\section{Bibliography}

Agamben, G. Homo Sacer. Sovereign Power and Bare Life. Stanford, Calif.: Stanford University Press, 1998.

Agamben, G. State of Exception. Chicago, Ill; London: University of Chicago Press, 2005.

Arendt, H. On Violence. Crises of the Republic, 103-184. New York: Harcourt Brace Jovanovich, 1972.

Arias, E. D., and C. D. Rodrigues. "The Myth of Personal Security: Criminal Gangs, Dispute Resolution, and Identity in Rio de Janeiro's Favelas." Latin American Politics and Society 48, no. 4 (2006): 53-81. doi:10.1111/j.1548-2456.2006.tb00365.x.

Becucci, S. "Criminal Infiltration and Social Mobilisation against the Mafia. Gela: A City between Tradition and Modernity." Global Crime 12, no. 1 (2011): 1-18. doi:10.1080/17440572.2011.548961.

Belyi, M. “Na ulitsy Rossii vernulis' molodyozhnye gruppirovki." Ura.ru, November 5, 2018. Accessed December 11, 2018. https://ura.news/articles/1036276678

Briquet, J.-L., and G. Favarel-Garrigues. "Introduction.” In Organized Crime and States: The Hidden Face of Politics, edited by J.-L. Briquet, G. Favarel-Garrigues, and R. Leverdier, 5-13. Basingstoke: Palgrave Macmillan, 2010.

Canetti, E. Crowds and Power. Harmondsworth: Penguin, 1973.

Collins, R. Violence: A Micro-sociological Theory. Princeton, N.J.; Woodstock: Princeton University Press, 2008.

Connell, R. Masculinities. Cambridge: Polity, 2005.

Densley, J. How Gangs Work: An Ethnography of Youth Violence. Houndmills: Palgrave Macmillan, 2013.

Esbensen, F.-A., D. Deterson, T. J. Terrance, and A. Freng. "Similarities and Differences in Risk Factors for Violent Offending and Gang Membership." Australian and New Zealand Journal of Criminology 42, no. 3 (2009): 310-335. doi:10.1375/acri.42.3.310.

Favarel-Garrigues, G. "Mafia Violence and Political Power in Russia." In Organized Crime and States: The Hidden Face of Politics, edited by J.-L. Briquet, G. Favarel-Garrigues, and R. Leverdier, 147-172. Basingstoke: Palgrave Macmillan, 2010.

Favarel-Garrigues, G. "Justiciers Amateurs et Croisades Morales en Russie Contemporaine." Revue Française de Science Politique 68, no. 4 (2018): 651-667. doi:10.3917/rfsp.684.0651.

Galeotti, M. The Vory. Russia’s Super Mafia. New Haven: Yale University Press, 2018.

Gambetta, D. The Sicilian Mafia: The Business of Private Protection. Cambridge, Mass.: Harvard University Press, 1993.

Garfinkel, H. Studies in Ethnomethodology. Englewood Cliffs, N.J.: Prentice-Hall, 1967.

Giddens, A. The Nation-state and Violence. Cambridge: Polity Press, 1985. 
Golovin, V. V., and M. L. Lurie. "Ideologicheskie i territorialnye soobshchestva molodeozhi: megapolis, provintsialnyi gorod, selo.” In Etnograficheskoe Obozrenie. 1, 56-70. 2008.

Gromov, D. V. "Podrostkovo-molodeozhnye ulichnye gruppirovki kak ob'ekt etnograficheskogo issledovaniia." In Molodeozhnye ulichnye gruppirovki: vvedenie v problematiku, edited by D. V. Gromov, 8-72. Moscow: IEA RAN, 2009. Guns.ru. Accessed November 8, 2017. https://forum.guns.ru/forummessage/38/178.html

Hallsworth, S., and T. Young. "Gang Talk and Gang Talkers: A Critique." Crime, Media, Culture 4, no. 2 (2008): 175-195. doi:10.1177/1741659008092327.

Hobbs, D., and G. Antonopoulos. "How to Research Organized Crime." In The Oxford Handbook of Organized Crime, edited by L. Paoli. Oxford: Oxford University Press, 2014. doi:10.1093/oxfordhb/ 9780199730445.013.010.

Humphrey, C. The Unmaking of Soviet Life. Everyday Economies after Socialism. Ithaca: Cornell University Press, 2002.

Humphrey, C. "Sovereignty." In A Companion to the Anthropology of Politics, edited by D. Nugent and J. Vincent, 418-436. Malden, Mass.: Blackwell, 2004.

Iskusstvo Boya. Accessed November 5, 2017. http://isskystvoboya.ru/samooborona/razgovorpoponyatiyam-ili-samooborona-ot-gopnikov

James, A. "The Practice of Sovereign Statehood in Contemporary International Society." Political Studies 47, no. 3 (1999): 462-464. doi:10.1111/1467-9248.00212.

Kafka, F. The Trial. New York: Schocken Books, 1998.

Kaminski, M. M. Games Prisoners Play: The Tragicomic Worlds of Polish Prison. Princeton: Princeton University Press, 2004.

Karbainov, N. I. “'Ei, khunkhuz, kuda idiosh? Zdes' bratva, i ty umriosh!': ‘ulichnye voiny' v Ulan-Ude. ” In Molodezhnye ulichnye gruppirovki: vvedenie v problematiku, edited by D. V. Gromov:, 132-148. Moscow: IEA RAN, 2009.

Katz, J. Seductions of Crime: Moral and Sensual Attractions in Doing Evil. New York: Basic Books, 1988.

Kirillov, A. "V kazan vernulis' gruppirovki." prokazan.ru. Accessed 10 April, 2019. http://prokazan.ru/news/view/124303

Konstantinov, A. Banditskii Peterburg. Dokumental'nye Ocherki. St. Petersburg: Neva, 2004.

Kostiuchenko, E. Nam Zdes' Zhit'. Moscow: AST, 2015.

Kozlov, A. S. 'Kozel na sakse': i tak vsiu zhizn. Moscow: Vagrius, 1998.

Latham, R. "Social Sovereignty." Theory, Culture and Society 17, no. 4 (2000): 1-18. doi:10.1177/02632760022051284.

Leibler, L. "Illegal Enterprises and the City: When Territorial Control Is an Issue of Urban Governance. Lessons from Meddelin, Colombia." In The Illicit and Illegal in Regional and 
Urban Governance and Development: Corrupt Places, edited by F. Chiodelli, T. Hall, and R. Hudson, 93-106. Milton Park, Abingdon, Oxon; New York, NY: Routledge, 2018.

Lozovskii, V. "Kto takie gopniki i kak sebia s nimi vesti." tuyrem.net. n. d. Accessed December 25, 2017. https://www.tyurem.net/mytext/look/047.htm.

Messerschmidt, J. W. Masculinities and Crime: Critique and Reconceptualization of Theory. Lanham, Md.: Rowman \& Littlefield, 1993.

North, D. C., J. J. Wallis, and B. R. Weingast. Violence and Social Orders: A Conceptual Framework for Interpreting Recorded Human History. Cambridge: Cambridge University Press, 2009.

Olson, M. "Dictatorship, Democracy, and Development." The American Political Science Review 87, no. 3 (1993): 567-576. doi:10.2307/2938736.

Paoli, L. "The Paradoxes of Organised Crime." Crime, Law and Social Change 37, no. 1 (2002): 51-97. doi:10.1023/A:1013355122531.

Pikabu.ru. "Chto delat esli na tebya napali gopniki." Accessed December 5, 2018. https://pikabu.ru/story/chto_delat_esli_napali_gopniki_5346024

Raleigh, D. J. Russia's Sputnik Generation: Soviet Baby Boomers Talk about Their Lives. Bloomington; Indianapolis: Indiana University Press, 2006.

Rodgers, D. J. "Joining the Gang and Becoming a Broder: The Violence of Ethnography in Contemporary Nicaragua.” Bulletin of Latin American Research 26, no. 4 (2007): 444-461. doi:10.1111/j.1470-9856.2007.00234.x.

Rodgers, D. J. "Living in the Shadow of Death: Gangs, Violence and Social Order in Urban Nicaragua, 1996-2002." In Youth Violence in Latin America, edited by D. Rodgers. and G. A. Jones, 25-44. New York: Palgrave Macmillan, 2009.

Salagaev, A., A. Shashkin, and A. Konnov. "One Hand Washes Another: Informal Ties between Organized Criminal Groups and Law-Enforcement Agencies in Russia." Journal of Power Institutions in Post-Soviet Societies, no. 4-5. (2006). Accessed March 1, 2019. http://pipss. revues.org/449

Schmitt, C. The Concept of the Political. Chicago: University of Chicago Press, 1996.

Sergi, A. "Mafia and Politics as Concurrent Governance Actors. Revisiting Political Power and Crime in Southern Italy." In The Relativity of Wrongdoing: Corruption, Organised Crime, Fraud and Money Laundering in Perspective, edited by P. C. van Duyne, A. Maljević, G. A. Antonopoulos, J. Harvey, and. von Lampe, 43-70. Oisterwijk: Wolf Legal Publishers, 2015.

Shashkin, A. "Ulitsa: svoi i chuzhie." In Molodezhnye ulichnye gruppirovki: vvedenie v problematiku, edited by D. V. Gromov:, 149-184. Moscow: IEA RAN, 2009.

Stephenson, S. "The Kazan Leviathan: Russian Street Gangs as Agents of Social Order." The Sociological Review 59, no. 2 (2008): 324-347. doi:10.1111/j.1467-954X.2011.02007.x. 
Stephenson, S. Gangs of Russia: From the Streets to the Corridors of Power. Ithaca: Cornell University Press, 2015.

Stephenson, S. "It Takes Two to Tango: The State and Organized Crime in Russia." Current Sociology 65, no. 3 (2017): 411-426. doi:10.1177/0011392116681384.

Stephenson, S., and E. Zakharova. "Criminal Networks, Youth Street Groups and Illicit Territorial Regulation in Moscow and Tbilisi." In In the Illicit and Illegal in Regional and Urban Governance and Development: Corrupt Places, edited by F. Chiodelli, T. Hall, and R. Hudson, 74-92. Milton Park, Abingdon, Oxon; New York, NY: Routledge, 2018.

Sukharenko, A. "Organized Crime in Russia." Per Concordiam. Journal of European Security andDefense Issues 4 (2014): 44-49.

Taylor, B. D. State Building in Putin's Russia: Policing and Coercion after Communism. Cambridge: Cambridge University Press, 2011.

Thrasher, F. M. The Gang. A Study of 1,313 Gangs in Chicago. London and Chicago: The University of Chicago Press, 1963.

Varese, F. The Russian Mafia: Private Protection in a New Market Economy. Oxford, England; New York: Oxford University Press, 2001.

Varese, F. "Protection and Extortion." In The Oxford Handbook of Organized Crime, edited by L. Paoli. Oxford: Oxford University Press, 2014: 343-358. doi:10.1093/oxfordhb/9780199730445.001.0001/oxfordhb-9780199730445-e-020.

Venkatesh, S. A. American Project: The Rise and Fall of a Modern Ghetto. Cambridge, Mass.: Harvard University Press, 2000.

Volkov, V. Violent Entrepreneurs: The Use of Force in the Making of Russian Capitalism. Ithaca, N.Y.: Cornell University Press, 2002.

Volkov, V. "Vvedenie." In Pravo i pravoprimenenie v Rossii: mezhdisdiplinarnie issledovaniia, edited by V. Volkov, 3-14. Moscow: Statut, 2011.

von Lampe, K. Organized Crime: Analyzing Illegal Activities, Criminal Structures and ExtraLegal Governance. Los Angeles: SAGE, 2016.

Weber, M. "Politics as Vocation." In From Max Weber: Essays in Sociology, edited by H. Herth and C. W. Mill. London: Routledge, 1970: pp. 77-128.

Zabyelina, Y. "Russia's Night Wolves Motorcycle Club: From 1\%ers to Political Activists." Trends in Organized Crime 22, no. 1 (2019): 51-65. doi:10.1007/s12117-017-9314-7.

Zdorovova, U. "A cho borzyi takoi?" Kto takie patsany i kak oni poiavliaiutsia V gorodakh.Rasskazyvaet antropolog.” Bumaga, December25, 2017. Accessed December 26, 2017. https://paperpaper.ru/patsan/ 